\title{
Hubungan kualitas informasi website RS Paru Dr. H. A. Rotinsulu dengan pemenuhan kebutuhan informasi
}

\author{
Hafizhah Nur Aghnia1, Neneng Komariah ${ }^{2}$, Edwin Rizal ${ }^{3}$ \\ 1 UPT Perpustakaan Institut Teknologi Sumatera (ITERA) \\ Jl. Terusan Ryacudu, Way Huwi, Jati Agung, Lampung Selatan, 35365 \\ 2,3 Program Studi Ilmu Perpustakaan, Universitas Padjadjaran \\ Jl. Raya Bandung-Sumedang Km. 21, Jatinangor, Sumedang, 45363 \\ E-mail: ${ }^{1}$ hanurania@gmail.com, ${ }^{2}$ neneng.komariah@unpad.ac.id, ${ }^{3}$ edwin.rizal@unpad.ac.id
}

Received: August 2018; Accepted: December 2019; Published: December 2019

\begin{abstract}
The official website of an institution on the quality of information about the institution's profile and the services offered at the institution can help for people who need information about hospital services. This study aimed to determine the relationship between the quality of information on the official website of Dr. H.A. Rotinsulu Hospital and meeting the information needs of visitors. This study used a quantitative correlational method with a study population of visitors to Dr. HA Rotinsulu, Lung Hospital website, who conducted online consultations, with a sample of 50 respondents was obtained. Research data were collected using questionnaires, interviews, and literature studies. The inferential correlation test used a simple linear regression analysis test using the product moment formula. The results showed a significant relationship between the quality of information, both from indicators of accuracy, timeliness, and relevance of information, with the fulfillment of cognitive needs and personal integrity of website visitors. This was proven by testing the mayor hypothesis, and the calculation results obtained a correlation coefficient of 0.738 with a coefficient of determination of 0.544 . Furthermore, it got a ${ }^{t}$ count of 8,253 and $a^{t}$ table of 1,677. Thus, the ${ }^{t}$ count was higher than the table, so the hypothesis was accepted. This means that website visitors considered that the information presented had high accuracy, high punctuality, and high relevance to meet cognitive needs and personal integrity. Then, the information presented on Dr. H.A. Rotinsulu Hospital website is of high quality and can meet the information needs of its visitors.
\end{abstract}

Keywords: Website; Information quality; Meeting information needs

\begin{abstract}
Abstrak
Website resmi lembaga yang berisi informasi berkualitas mengenai profil lembaga dan layanan dapat membantu masyarakat yang membutuhkan informasi tentang layanan RS. Penelitian ini bertujuan untuk mengetahui hubungan antara kualitas informasi website resmi RS Dr. HA Rotinsulu dengan pemenuhan kebutuhan informasi pengunjungnya. Penelitian ini menggunakan metode penelitian kuantitatif korelasional dengan populasi penelitian pengunjung website RS Paru Dr. HA Rotinsulu yang pernah melakukan konsultasi online, dengan sampel yang diperoleh sebanyak 50 responden. Data penelitian dikumpulkan menggunakan angket, wawancara, dan studi kepustakaan. Uji korelasi inferensial menggunakan uji analisis regresi linear sederhana dengan menggunakan rumus product moment. Hasil penelitian membuktikan terdapat hubungan yang signifikan antara kualitas informasi baik dari indikator keakuratan, ketepatan waktu, dan relevansi informasi, dengan pemenuhan kebutuhan kognitif dan integritas personal pengunjung website. Hal ini dibuktikan melalui pengujian hipotesis mayor, yaitu hasil penghitungan didapatkan koefisien korelasi 0,738 dengan koefisien determinasi 0,544. Selanjutnya didapatkan thitung 8,253 dan tabel 1,677. Dengan demikian thitung lebih besar dari tabel, sehingga hipotesis diterima. Para pengunjung website menilai bahwa informasi yang disajikan memiliki keakuratan yang tinggi, ketepatan waktu yang tinggi, serta relevansi yang tinggi, sehingga mampu memenuhi kebutuhan kognitif dan integritas personal. Maka, website RS Dr. HA Rotinsulu memiliki kualitas yang baik dan dapat memenuhi kebutuhan informasi pengunjungnya.
\end{abstract}

Kata Kunci: Website; Kualitas informasi; Pemenuhan kebutuhan informasi 


\section{PENDAHULUAN}

Pada era teknologi sekarang ini, informasi bisa didapatkan dari mana saja melalui banyak media, seperti media cetak, yaitu koran, majalah, pamflet, maupun media elektronik, yaitu portal berita online, website, TV, dan radio. Salah satu media yang paling populer pada era sekarang ini adalah internet, khususnya website.

Hidayat (2010) dalam Syukron and Hasan (2015) mengatakan bahwa, "Website adalah kumpulan halaman-halaman yang digunakan untuk menampilkan informasi teks, gambar, diam atau gerak, animasi, suara, dan atau gabungan dari semuanya, baik yang bersifat statis maupun dinamis yang membentuk satu rangkaian bangunan yang saling terkait, yang masing-masing dihubungkan dengan jaringan-jaringan halaman." Website dapat memuat banyak informasi serta pelayanan lain yang dilakukan secara online. Dewi and Garside (2014) mengutarakan ada beberapa manfaat penggunaan website bagi lembaga/perusahaan antara lain untuk meningkatkan promosi perusahaan dalam mengenalkan produk atau layanan yang diberikan pada pengguna. Perusahaan menggunakan website dapat memangkas biaya pemasaran, karena website sangat efektif menjangkau semua pengguna yang menyimpan banyak konten, misalnya media sosial, foto, video dan audio.

Salah satu kelebihan website adalah dapat diakses secara online sehingga pengguna akan mudah mencari informasi. Pengguna dapat berada di mana pun, sepanjang tersedia fasilitas akses internet, akan dapat mengakses website tersebut. Jadi, pengguna dalam proses memperoleh informasi tidak dibatasi jarak dan waktu.

Oleh karena itu, bagi suatu lembaga atau perusahaan di era teknologi sekarang ini, memiliki website merupakan sebuah keniscayaan. Namun website yang dimiliki oleh suatu lembaga harus merupakan website yang berkualitas. Kualitas website dapat diukur menggunakan metode WebQual. Metode ini merupakan pengembangan dari ServQual yang merupakan metode yang digunakan untuk mengukur kualitas layanan. Menurut Barnes and Vidgen (2002) dalam Ellyusman and Hutami (2017), WebQual, "Merupakan metode yang digunakan untuk mengukur bagaimana kualitas sebuah website, melalui 3 indikator, kemudahan penggunaan (usability), kualitas informasi (information quality), serta kualitas interaksi layanan (service interaction quality)."

Website membantu sebuah lembaga dalam mengkomunikasikan jasa atau produk perusahaan yang ditawarkan melalui informasi yang dapat diakses dengan mudah oleh pelanggan. Begitu pun website resmi yang dimiliki oleh RS Paru Dr. H. A. Rotinsulu. Website ini menyediakan beberapa fitur layanan yang paling banyak diakses oleh masyarakat.

"Jadwal dokter; tarif layanan berupa rawat jalan, rawat inap, dan tarif pelayanan rontgen; informasi tentang instalasi gawat darurat; informasi tentang rawat jalan; informasi tentang rawat inap yang berisi daftar ruang, kelas ruangan, dan jumlah tempat tidur; informasi tentang intensive care unit (ICU); informasi tentang penunjang medis seperti laboratorium, radiologi, rehabilitasi medis, diagnostik elektro medik, tindakan medik, dan farmasi; informasi tentang profil dokter yang tersedia di RS, yang terdiri dari 14 dokter spesialis, 17 dokter umum, dan 
1 dokter gigi"(Rumah Sakit Paru Dr.

H. A. Rotinsulu, 2019).

Ketika seseorang sedang memilih RS, terdapat banyak faktor yang akan menentukan, di antaranya, "Faktor tersebut secara acak adalah promosi, kualitas, situs internet tentang RS, rekomendasi, rujukan, tarif, pelayanan pekerja RS, pengalaman, dan jarak (Kusumawati, 2013). Pada hasil penelitian tersebut dapat diketahui bahwa situs internet atau website RS merupakan salah satu faktor yang diperhatikan sebelum memilih suatu RS. Sebuah website RS dapat menginformasikan banyak hal, seperti informasi tentang promosi, profil RS, jadwal praktik dokter, alamat dan kontak yang dapat dihubungi, profil dokter yang praktik, fasilitas dan tarif, serta informasi mengenai promosi kesehatan.

Jadi, website RS juga terbukti memudahkan pasien atau keluarga pasien dalam mencari informasi seputar medis. Selain itu, "Sistem informasi yang dibuat telah berhasil memudahkan pasien maupun keluarga pasien dalam mencari informasi medis yang dibutuhkan" (Susilowati \& Riasti, 2011). Menarik untuk diketahui bahwa, bagaimana kualitas informasi dalam website dalam hubungannya dengan pemenuhan kebutuhan informasi para pengunjung website tersebut.

Layanan dalam sebuah RS merupakan hal penting yang harus diperhatikan. Sebuah RS akan semakin dipercaya apabila memiliki pelayanan yang baik dan beragam. Namun informasi mengenai pelayanan di suatu RS sering kali tidak tersedia. Sesuai Peraturan Menteri Kesehatan Republik Indonesia Nomor 4 Tahun 2018 tentang kewajiban RS dan kewajiban pasien dalam Palindo
(2019), dijelaskan pada Bab II pasal 2 bahwa, setiap RS wajib memberikan informasi yang benar tentang pelayanan RS kepada masyarakat. Selanjutnya diperjelas pada pasal 3 bahwa, informasi yang dimaksud meliputi informasi umum tentang RS dan informasi yang berkaitan dengan pelayanan medis kepada pasien.

Secara konvensional, sebelum masuknya era internet, RS menyediakan informasi mengenai pelayanan melalui media pamflet, booklet, atau malah tidak tersedia informasi sama sekali. Dengan demikian, informasi mengenai pelayanan dapat lebih mudah tersampaikan melalui website. Informasi dapat disajikan secara jelas dan terperinci pada halaman website yang dimiliki RS. Informasi tersebut dapat bermanfaat bagi calon pasien yang sedang mencari RS atau pasien yang sedang membutuhkan pelayanan.

Ada beberapa penelitian yang sudah membahas mengenai kualitas informasi. Pertama, penelitian Ardy (2017) dan penelitian Nababan (2017). Berdasarkan kedua penelitian tersebut menunjukkan bahwa terdapat hubungan antara kualitas informasi dengan pemenuhan kebutuhan informasi pengguna. Kesamaan kedua penelitian tersebut dengan penelitian ini adalah membahas hubungan kualitas informasi dari akun resmi sebuah institusi dengan pemenuhan kebutuhan informasi penggunanya. Adapun perbedaannya adalah kedua penelitian tersebut membahas kualitas informasi pada akun media sosial, sedangkan penelitian ini membahas website RS.

Selanjutnya penelitian lain yang dilakukan Oktaviana (2017). Penelitian ini memiliki kesamaan dengan penelitian ini dalam menggunakan teori kualitas informasi sebagai variabel bebas melalui tiga indikator kualitas informasi, yakni 
keakuratan, ketepatan waktu, serta relevansi informasi. Namun penelitian Oktaviana (2017) hanya meneliti kebutuhan informasi sebagai satu variabel terikat. Untuk variabel kebutuhan informasi menggunakan teori dari Katz, Gurevitch, and Haas yang juga digunakan dalam penelitian ini.

$\begin{array}{crr}\text { Hasil } & \text { penelitian } & \text { tersebut } \\ \text { menunjukkan } & \text { bahwa, } & \text { "Terdapat }\end{array}$
pengaruh baik dari keakuratan, ketepatan waktu, relevansi informasi pada website www.pbhmi.or.id dengan pemenuhan kebutuhan informasi" (Oktaviana, 2017). Adapun perbedaan penelitian terletak pada hipotesis penelitian. Penelitian Oktaviana (2017) melakukan uji pengaruh sedangkan penelitian ini menguji hubungan. Maka, hasil penelitian ini akan saling melengkapi.

Penelitian ini dilakukan untuk mengetahui hubungan kualitas informasi pada website RS Paru Dr. H. A. Rotinsulu yang beralamat di rsparurotinsulu.org dengan pemenuhan kebutuhan informasi pengunjung. Secara spesifik, tujuan penelitian untuk mengetahui beberapa hal. Pertama, untuk mengetahui hubungan antara informasi yang akurat dengan pemenuhan kebutuhan kognitif. Kedua, untuk mengetahui hubungan informasi yang akurat dengan pemenuhan kebutuhan integrasi personal. Ketiga, untuk mengetahui hubungan antara informasi yang tepat waktu dengan pemenuhan kebutuhan kognitif. Keempat, untuk mengetahui hubungan antara informasi yang tepat waktu dengan pemenuhan kebutuhan integrasi personal. Kelima, untuk mengetahui hubungan antara informasi yang relevan dengan pemenuhan kebutuhan kognitif. Keenam, untuk mengetahui hubungan antara informasi yang relevan dengan pemenuhan kebutuhan integrasi personal. Dengan demikian, hasil dari penelitian ini diharapkan dapat dijadikan referensi dalam pengembangan website RS Paru Dr. H. A. Rotinsulu.

Dretske (1981) dalam McKinney Jr and Yoos II (2019) menulis, "Specifies further - that information is the regularity, the causal dependence, of the sign on the object as in smoke (a sign) depends on fire." Informasi menjadi tanda dari sebuah keteraturan. Tanda di sini ialah data yang digunakan untuk dikirimkan kepada khalayak. Lalu ditambahkan juga,

"Information is the meaning that results from data processing, commonly, information is processed data. Information rests on data, is inferred from data. Information and data are objectively true, as they correspond to real or abstract object" (McKinney Jr, \& Yoos II, 2019). Informasi berasal dari data yang telah diproses. Maka, informasi bertumpu pada data. Oleh karena itu, data yang akan dihasilkan menjadi informasi haruslah data yang objektif. Hartono (2017) dalam Putra and Febriani (2013) menggambarkan, kualitas informasi dalam bentuk bangunan yang ditunjang tiga buah pilar, di antaranya akurat, tepat waktu, relevan.

Pertama, informasi yang akurat. Informasi harus mencerminkan keadaan yang sebenarnya sesuai fakta. Badan Pengembangan dan Pembinaan Bahasa Kementerian Pendidikan \& Kebudayaan (2019a) menyatakan bahwa kata akurat berarti, "Teliti, saksama, cermat, dan tepat benar." Informasi yang ditulis dengan teliti dan cermat akan meminimalkan kesalahan sehingga informasi tersebut benar dan sesuai fakta. Kedua, informasi yang tepat waktu. Penerima menerima informasi tidak boleh terlambat. Informasi 
yang sudah usang tidak akan memiliki nilai lagi, karena informasi merupakan dasar pembuatan suatu keputusan. Ketiga, informasi yang relevan. Informasi yang ada harus memiliki manfaat bagi pengguna. Badan Pengembangan dan Pembinaan Bahasa Kementerian Pendidikan \& Kebudayaan (2019b) pun mengartikan relevan, "Berguna secara langsung." Kegunaan tersebut juga berkaitan dengan kebutuhan pengguna. Di mana penyediaan informasi yang relevan akan memenuhi kebutuhan pengguna.

Katz, Gurevitch, and Haas (1973) dalam Yusup (2017) menjelaskan bahwa,

"Manusia sebagai makhluk hidup memiliki kebutuhan yang harus dipenuhi dalam rangka pengembangan diri mulai dari kebutuhan kognitif, afektif, integritas personal, integritas sosial, dan berkhayal. Kebutuhan kognitif berkaitan dengan pengetahuan dan pemahaman seseorang dalam lingkungannya. Kebutuhan ini didasarkan pada keinginan seseorang individu untuk menguasai dan memahami lingkungan. Pemenuhan kebutuhan ini akan menghasilkan kepuasan terhadap rasa ingin tahu serta hasrat penyelidikan individu."

Kebutuhan afektif berhubungan dengan kebutuhan estetis. Individu akan menerima hal yang menyenangkan dan memberikan pengalaman emosional. Adapun kebutuhan afeksi bermakna rasa penghargaan diri terhadap situasi, kondisi, waktu, lingkungan, dan juga orang lain, sedangkan kebutuhan integritas personal berkaitan dengan penguatan kredibilitas, stabilitas, dan status individu. Semua kebutuhan ini berasal dari hasrat seseorang untuk mencari harga diri. Kepercayaan diri seseorang akan timbul ketika ia merasa memiliki informasi yang dia perlukan. Seorang individu akan merasa lebih percaya diri apabila memiliki informasi sehingga merasa dapat menguasai keadaan atau lingkungan.

Selain itu, kebutuhan integritas sosial suatu individu yang berhubungan dengan kebutuhan komunikasi dengan orang di lingkungan sekitar, termasuk keluarga, teman, maupun orang yang tidak dikenal. Kebutuhan ini berasal dari keinginan seseorang untuk berkomunikasi dengan orang atau kelompok lain. Aplikasi dalam kehidupan nyata berupa penggunaan media sosial untuk memenuhi hasrat bersosialisasi dan mendapatkan informasi. Kebutuhan berkhayal yang dimaksud adalah kebutuhan yang berkaitan kebutuhan untuk melarikan diri, melepas ketegangan, dan hasrat untuk mencari hiburan. Pada masa sekarang, kebutuhan ini dapat diakomodasi melalui internet. Internet dapat menjadi pemenuhan kebutuhan sosial sekaligus sosial. Di mana individu menggunakan internet menjadi tempat bersosialisasi dengan orang lain dan menjadi media yang bersifat asosial.

Pada penelitian ini, peneliti menggunakan dua indikator dari lima indikator, yakni kebutuhan kognitif dan kebutuhan integritas personal. Hal ini berkaitan dengan kebutuhan pengguna website itu sendiri. Peneliti menilai bahwa informasi dalam website RS merupakan informasi yang dengan sengaja dicari oleh seorang individu. Apabila seorang individu tersebut dapat menemukan informasi yang dibutuhkan, maka setidaknya dua indikator kebutuhan individu tersebut telah terpenuhi. Oleh karena itu, tujuan penelitian ini adalah 
untuk mengetahui hubungan antara informasi yang akurat, tepat waktu, dan relevan dalam website RS Dr. H. A. Rotinsulu dengan pemenuhan kebutuhan kognitif dan integrasi personal.

Seorang individu yang membuka website suatu RS sudah pasti membutuhkan informasi mengenai RS tersebut. Maka, individu yang telah mendapatkan informasi akan terpenuhi kebutuhan kognitif sehingga pengetahuan dan pemahamannya jadi bertambah. Ketika individu tersebut mendapatkan informasi dan memutuskan untuk datang secara langsung ke RS, maka kebutuhan integritas personalnya akan terpenuhi. Kebutuhan integritas personal berhubungan dengan kepercayaan diri seseorang. Seorang individu akan merasa lebih percaya diri dengan memiliki informasi sehingga merasa menguasai keadaan atau lingkungannya. Dengan demikian, individu yang datang ke RS secara langsung akan mengetahui apa yang harus dilakukan.

\section{METODE PENELITIAN}

Penelitian ini menggunakan metode penelitian kuantitatif dengan pendekatan korelasional. Penelitian korelasional menggambarkan suatu pendekatan umum untuk penelitian yang berfokus pada penaksiran korelasi di antara variabel yang muncul secara alami. Emzir (2008) dalam Arizona (2014) menyatakan bahwa penelitian korelasi dapat membantu mengidentifikasi hubungan prediktif menggunakan teknik korelasi.

Populasi pada penelitian ini adalah pengunjung website RS Dr. H. A. Rotinsulu yang pernah melakukan konsultasi secara online pada laman website rsparurotinsulu.org/consultation sejak bulan Juni 2017 hingga bulan Juni 2018. Berdasarkan data awal penelitian yang didapatkan, pengunjung website RS Dr. H. A. Rotinsulu yang pernah melakukan konsultasi online ini berjumlah 90 orang. Pada penelitian ini, peneliti menggunakan probability sampling dengan teknik acak sederhana (simple random sampling). Jumlah sampelnya dihitung menggunakan rumus Slovin (1960) dalam Hanany and Sudirman (2019) dengan rumus sebagai berikut:

$$
\mathrm{n}=\frac{N}{1+N x^{2}}
$$

Dengan keterangan,

$$
\begin{array}{ll}
\mathrm{n}= & \text { jumlah sampel } \\
\mathrm{N}= & \text { jumlah populasi } \\
\mathrm{x}= & \text { Inur } \mathrm{gin} \text { of } \text { etrut }
\end{array}
$$

Maka, apabila menggunakan margin eror sebesar $10 \%$ dengan rumus Slovin akan didapatkan jumlah sampel

$$
n=\frac{\mathrm{cn}}{1+90(10 \%)^{2}}
$$

$\mathrm{n}=\frac{90}{1, y}$

$\mathrm{n}=\quad 47,3$ atau 48, dibulatkan menjadi 50 Teknik pengumpulan data utama menggunakan angket yang dibagikan langsung kepada responden. Angket adalah sekumpulan data tertulis yang diberikan kepada responden, dan akan dijawab secara tertulis juga. Angket yang digunakan pada penelitian ini merupakan angket tertutup. Angket dibuat dalam versi digital menggunakan Google Form lalu dibagikan melalui tautan (link) kepada responden. Peneliti berpendapat bahwa penggunaan angket digital akan menghemat waktu serta biaya yang 
dikeluarkan baik bagi penulis maupun responden.

Teknik pengumpulan data lainnya melalui studi kepustakaan merupakan kegiatan penghimpunan informasi dari berbagai bahan pustaka yang ada. Bahan pustaka tersebut berupa buku, jurnal, skripsi, tesis, artikel ilmiah, ensiklopedia, dan lain sebagainya. Informasi yang diperoleh melalui studi pustaka dapat menunjang data yang terkumpul melalui angket.

Selain itu, peneliti pun melakukan observasi secara langsung untuk mengumpulkan data dari responden. Arifin (2011) dalam Chairunisa, Sukirman, and Setiawati (2019) mengatakan bahwa observasi menjadi sebuah pengamatan dari satu fenomena yang diteliti peneliti harus membuka diri dari temuan data yang diperoleh lalu menganalisisnya. Peneliti dalam melakukan observasi melalui pengamatan dari subjek mengenai situasi yang sedang diteliti. Lalu, peneliti menganalisis data hasil observasi dengan cara membuat perbandingan dan memilih informasi yang relevan untuk digunakan dalam mendukung analisis data yang diperoleh melalui angket.

\section{HASIL DAN PEMBAHASAN}

Johnson and Martin (2014) menyatakan bahwa sumber rujukan utama bagi pasien RS, calon pasien, keluarga, media dan profesional kesehatan adalah melalui website. Maka, website RS menjadi penting sebagai media komunikasi RS kepada pihak luar. Website RS Dr. H. A. Rotinsulu merupakan situs organisasi non pemerintah, yaitu merupakan situs resmi milik lembaga swasta dalam hal ini RS yang berorientasi non profit.

Pembahasan dalam penelitian ini, diawali analisis deskriptif profil responden penelitian. Sesuai tabel interpretasi persentase yang dirumuskan Riduwan (2012) dalam Dipraya and Suwito (2015), profil responden adalah sebagai berikut, dilihat dari aspek jenis kelamin sebagian besar (54\%) responden adalah perempuan, dan sebagian besar (60\%) dari mereka berusia 15-25 tahun. Selanjutnya hampir seluruh $(80 \%)$ dari responden menggunakan smartphone untuk mengakses internet, dan hampir seluruh $(80 \%)$ dari mereka menggunakan mesin pencari untuk menemukan website RS.

Sebagian besar dari responden (74\%), mengakses website RS Dr. H. A. Rotinsulu lebih dari satu kali, yang bertujuan mencari informasi mengenai layanan RS. Pada umumnya, pengunjung website RS Dr. H. A. Rotinsulu adalah perempuan usia muda yang sudah mahir mengakses internet menggunakan smartphone. Responden sering mengakses website RS untuk keperluan mencari informasi mengenai layanan.

Dengan demikian, informasi mengenai layanan yang tersedia di RS merupakan informasi yang paling banyak dibutuhkan masyarakat. Masyarakat menjadi sangat mudah mendapatkan informasi melalui informasi yang tersedia di website, tanpa harus datang secara langsung dalam memilih RS sebagai tempat mereka berobat. Selanjutnya, peneliti melakukan analisis deskriptif pada setiap indikator kualitas informasi website dan indikator pemenuhan kebutuhan informasi berdasarkan frekuensi jawaban responden. Adapun indikator kualitas informasi website adalah keakuratan, ketepatan dan relevansi informasi, sedangkan indikator pemenuhan kebutuhan informasi adalah 
kebutuhan kognitif dan kebutuhan integritas personal.

Berdasarkan indikator kualitas informasi website, pertama adalah keakuratan. Pada indikator keakuratan informasi, hampir seluruh responden memiliki frekuensi 43 dan persentase $86 \%$. Responden menganggap bahwa informasi pada website RS Dr. H. A. Rotinsulu memiliki tingkat akurasi yang tinggi. Sementara itu, responden yang berjumlah sedikit menganggap bahwa informasi pada website RS Dr. H. A. Rotinsulu memiliki keakuratan yang sedang, berupa frekuensi 6 dan persentase $12 \%$, dan keakuratan rendah dengan frekuensi 1 dengan persentase 2\% responden. Maka, dapat disimpulkan bahwa responden menganggap informasi pada website RS Dr. H. A. Rotinsulu memiliki tingkat keakuratan yang tinggi. Hal ini artinya informasi yang diketahui melalui website telah sesuai kenyataan yang mereka alami ketika datang ke RS tersebut.

Kedua, indikator kualitas informasi website berdasarkan ketepatan waktu. Pada frekuensi ketepatan waktu informasi, sebagian besar responden menganggap bahwa informasi pada website RS Dr. H. A. Rotinsulu memiliki ketepatan waktu yang tinggi, dengan frekuensi 30 dan persentase $60 \%$ responden. Sementara itu, sebagian kecil responden menganggap bahwa informasi pada website RS Dr. H. A. Rotinsulu memiliki ketepatan waktu yang sedang, berupa frekuensi 18 dengan persentase $36 \%$. Adapun responden yang sangat sedikit menganggap ketepatan waktunya rendah, ditandai frekuensi 2 dengan persentase $4 \%$ responden. Sesuai hal ini, dapat disimpulkan bahwa responden menganggap informasi pada website RS Dr. H. A. Rotinsulu memiliki ketepatan waktu yang tinggi, artinya informasi yang terdapat di website sesuai dengan kenyataan yang mereka alami.

Ketiga, indikator kualitas informasi website berdasarkan relevansi. Pada frekuensi relevansi informasi, sebagian besar responden menganggap bahwa informasi pada website RS Dr. H. A. Rotinsulu memiliki relevansi yang tinggi, dengan frekuensi 38 dan persentase $76 \%$ responden. Sementara itu, sangat sedikit responden yang menganggap bahwa informasi pada website RS Dr. H. A. Rotinsulu memiliki relevansi yang sedang, dengan frekuensi 11 dan persentase 22\% responden. Adapun, responden yang menganggap ketepatan waktunya rendah dengan frekuensi 1 dan persentase 2\% responden. Maka, dapat disimpulkan bahwa responden menganggap informasi pada website RS Dr. H. A. Rotinsulu memiliki relevansi yang tinggi. Hal ini memiliki arti bahwa informasi dalam website merupakan informasi yang mereka butuhkan sehingga bermanfaat buat mereka.

Berdasarkan dalam indikator pemenuhan kebutuhan informasi terdapat dua indikator, di antaranya kebutuhan kognitif dan integritas personal. Pertama, kebutuhan kognitif. Pada frekuensi pemenuhan kebutuhan kognitif, hampir seluruh responden menganggap bahwa informasi pada website RS Dr. H. A. Rotinsulu memiliki tingkat pemenuhan kebutuhan kognitif yang tinggi dengan frekuensi 43 dan persentase 86\% responden. Sementara itu, sedikit responden yang menganggap bahwa informasi pada website RS Dr. H. A. Rotinsulu memiliki tingkat pemenuhan kebutuhan kognitif yang sedang, dengan frekuensi 6 dan 12\% responden. Selain itu, responden yang menganggap bahwa informasi pada website RS Dr. H. A. 
Rotinsulu memiliki tingkat pemenuhan kebutuhan kognitif yang rendah dengan frekuensi 1 dan persentase $2 \%$ responden. Maka, dapat disimpulkan bahwa responden menganggap informasi pada website RS Dr. H. A. Rotinsulu memiliki tingkat pemenuhan kebutuhan kognitif yang tinggi.

Selanjutnya, indikator pemenuhan kebutuhan informasi yang kedua, adalah kebutuhan integritas personal. Pada frekuensi pemenuhan kebutuhan integritas personal, hampir seluruh responden menganggap bahwa informasi pada website RS Dr. H. A. Rotinsulu memiliki tingkat pemenuhan kebutuhan integritas personal yang tinggi, dengan frekuensi 40 dan persentase $80 \%$ responden. Sementara itu, responden yang berjumlah sangat sedikit menganggap bahwa informasi pada website RS Dr. H. A. Rotinsulu memiliki tingkat pemenuhan kebutuhan integritas personal yang sedang dengan frekuensi 9 dan persentase $18 \%$ responden.

Adapun responden yang menganggap bahwa informasi pada website RS Dr. H. A. Rotinsulu memiliki tingkat pemenuhan kebutuhan integritas personal yang rendah dengan frekuensi 1 dan persentase 2\%. Dengan demikian, dapat disimpulkan bahwa responden menganggap informasi pada website RS Dr. H. A. Rotinsulu memiliki tingkat pemenuhan kebutuhan kebutuhan integritas personal yang tinggi. Sesuai dengan tujuan penelitian, berikut akan dijelaskan tabel yang menggambarkan hubungan antara kualitas informasi website dengan pemenuhan kebutuhan informasi. Penghitungan data menggunakan analisis koefisien korelasi dengan hasil tertera di bawah ini.

Pada tabel 1 (daftar tabel), didapatkan koefisien korelasi 0,680, dengan koefisien determinasi 0,462 dan jumlah sampel 50 . Nilai $t_{\text {tabel }}$ untuk jumlah responden 50 ( $\mathrm{dk}=$ $50-2=48)$ adalah 1,677 sehingga $t_{\text {hitung }}$ $(6,427) \geq t_{\text {tabel }}(1,677)$ maka $\mathrm{H}_{0}$ ditolak dan $\mathrm{H}_{1}$ diterima yang berarti keakuratan informasi pada website RS Dr. H. A. Rotinsulu memiliki hubungan yang signifikan dengan pemenuhan kebutuhan kognitif dan hubungan tersebut bersifat kuat. Dengan demikian, informasi pada website RS Dr. H. A. Rotinsulu memiliki tingkat keakuratan yang tinggi sehingga dinilai dapat memenuhi kebutuhan kognitif pengunjung.

Pada tabel 2 (daftar tabel), didapatkan koefisien korelasi 0,723, dengan koefisien determinasi 0,522 dan jumlah sampel 50 . Nilai $t_{\text {tabel }}$ untuk jumlah responden 50 (dk= $50-2=48$ ) adalah 1,677 sehingga thitung $(7,235) \geq t_{\text {tabel }}(1,677)$ maka $\mathrm{H}_{0}$ ditolak dan $\mathrm{H}_{1}$ diterima yang berarti keakuratan informasi pada website RS Dr. H. A. Rotinsulu memiliki hubungan yang signifikan dengan pemenuhan kebutuhan integritas personal dan hubungan tersebut bersifat sangat kuat. Jadi, informasi pada website RS Dr. H. A. Rotinsulu memiliki tingkat keakuratan yang tinggi sehingga dinilai dapat memenuhi kebutuhan integritas personal pengunjung.

Pada tabel 3 (daftar tabel), didapatkan koefisien korelasi 0,567, dengan koefisien determinasi 0,321 dan jumlah sampel 50 . Nilai $t_{\text {tabel }}$ untuk jumlah responden 50 ( $\mathrm{dk}=$ $50-2=48$ ) adalah 1,677 sehingga thitung $(4,766) \geq t_{\text {tabel }}(1,677)$ maka $\mathrm{H}_{0}$ ditolak dan $\mathrm{H}_{1}$ diterima yang berarti ketepatan waktu informasi pada website RS Dr. H. A. Rotinsulu memiliki hubungan yang signifikan dengan pemenuhan kebutuhan kognitif dan hubungan tersebut bersifat kuat. Dengan demikian, informasi pada website RS Dr. H. A. Rotinsulu memiliki 
tingkat ketepatan waktu yang tinggi sehingga dinilai dapat memenuhi kebutuhan kognitif pengunjung.

Pada tabel 4 (daftar tabel), didapatkan koefisien korelasi 0,608, dengan koefisien determinasi 0,369 dan jumlah sampel 50. Nilai $t_{\text {tabel }}$ untuk jumlah responden $50(\mathrm{dk}=$ 50-2 = 48) adalah 1,677 sehingga thitung $(5,304) \geq t_{\text {tabel }}(1,677)$ maka $\mathrm{H}_{0}$ ditolak dan $\mathrm{H}_{1}$ diterima yang berarti ketepatan waktu informasi pada website RS Dr. H. A. Rotinsulu memiliki hubungan yang signifikan dengan pemenuhan kebutuhan integritas personal dan hubungan tersebut bersifat kuat. Dengan demikian, informasi pada website RS Dr. H. A. Rotinsulu memiliki tingkat ketepatan waktu yang tinggi sehingga dinilai dapat memenuhi kebutuhan integritas personal pengunjung.

Pada tabel 5 (daftar tabel), didapatkan koefisien korelasi 0,661, dengan koefisien determinasi 0,436 dan jumlah sampel 50 . Nilai $t_{\text {tabel }} u$ tuk jumlah responden $50(\mathrm{dk}=$ 50-2 = 48) adalah 1,677 sehingga thitung $(6,105) \geq t_{\text {tabel }}(1,677)$ maka $\mathrm{H}_{0}$ ditolak dan $\mathrm{H}_{1}$ diterima yang berarti relevansi informasi pada website RS Dr. H. A. Rotinsulu memiliki hubungan yang signifikan dengan pemenuhan kebutuhan kognitif dan hubungan tersebut bersifat kuat. Dengan demikian, informasi pada website RS Dr. H. A. Rotinsulu memiliki tingkat relevansi yang tinggi sehingga dinilai dapat memenuhi kebutuhan kognitif pengunjung.

Berdasarkan tabel 6 (daftar tabel), didapatkan koefisien korelasi 0,738, dengan koefisien determinasi 0,544 dan jumlah sampel 50. Nilai tabel untuk jumlah responden $50(\mathrm{dk}=50-2=48)$ adalah 1,677 sehingga thitung $(7,574) \geq t_{\text {tabel }}(1,677)$ maka $\mathrm{H} 0$ ditolak dan $\mathrm{H} 1$ diterima yang berarti relevansi informasi pada website RS Dr. H.
A. Rotinsulu memiliki hubungan yang signifikan dengan pemenuhan kebutuhan integritas personal dan hubungan tersebut bersifat sangat kuat. Dengan demikian, informasi pada website RS Dr. H. A. Rotinsulu memiliki tingkat relevansi yang tinggi sehingga dinilai dapat memenuhi kebutuhan integritas personal pengunjung.

Secara keseluruhan, kualitas informasi website RS Dr. H. A. Rotinsulu dinilai baik oleh para pengunjungnya dan dapat memenuhi kebutuhan kognitif dan kebutuhan integritas personal mereka. Menurut Komariah, Rodiah, and Rakhmat (2018), website yang memiliki kualitas baik dapat memudahkan pencari informasi untuk mendapatkan informasi yang dibutuhkan. Hal ini dapat menjadikan pengguna merasa puas dan dapat meningkatkan citra lembaga yang bersangkutan. Dengan demikian, penilaian yang baik pada website RS Dr. H. A. Rotinsulu dapat meningkatkan citra baik pada RS tersebut.

\section{SIMPULAN}

Berdasarkan uji korelasi dan uji signifikan yang telah dibahas sebelumnya mengenai hubungan kualitas informasi website RS Paru Dr. H. A. Rotinsulu dengan pemenuhan kebutuhan informasi, maka didapatkan kesimpulan bahwa informasi yang berkualitas dari segi keakuratan, ketepatan waktu, serta relevan dapat memenuhi kebutuhan informasi pengunjung website RS Paru Dr. H. A. Rotinsulu. Informasi yang akurat dapat memenuhi kebutuhan pengetahuan dan wawasan bagi pengunjung website RS Paru Dr. H. A. Rotinsulu. Selain itu, informasi yang akurat juga dapat memenuhi kebutuhan percaya diri serta perasaan lebih baik 
pengunjung website RS Paru Dr. H. A. Rotinsulu. Selanjutnya informasi yang tepat waktu ternyata dapat memenuhi kebutuhan wawasan, pengetahuan serta dapat memenuhi kebutuhan kepercayaan diri serta perasaan lebih baik pengunjung website RS Paru Dr. H. A. Rotinsulu. Adapun informasi yang relevan dapat memenuhi kebutuhan responden dalam hal memberikan wawasan dan pengetahuan, serta menimbulkan rasa percaya diri dan perasaan lebih baik bagi pengunjung website RS Dr. H. A. Rotinsulu.

\section{DAFTAR PUSTAKA}

Ardy, R. R. (2017). Hubungan antara kualitas informasi instagram my trip my adventure dengan pemenuhan kebutuhan informasi destinasi wisata (Skripsi). Universitas Padjadjaran, Sumedang.

Arizona, S. (2014). Pengembangan media pembelajaran permainan interaktif kosakata bahasa Jepang "moji village" berbasis markerless motion capture untuk meningkatkan kemampuan kosakata kana dan kanii di SMA. Hikari, 2(2), 1-11. Retrieved from https://jurnalmahasiswa.unesa.ac.id /index.php/kejepanganunesa/article/view/8691

Badan Pengembangan dan Pembinaan Bahasa Kementerian Pendidikan \& Kebudayaan. (2019a). Kamus besar bahasa Indonesia (KBBI). Retrieved from https://www.kbbi.web.id/ website:

https://www.kbbi.web.id/akurat

Badan Pengembangan dan Pembinaan Bahasa Kementerian Pendidikan \& Kebudayaan. (2019b). Kamus besar bahasa Indonesia (KBBI). Retrieved from www.kbbi.web.id website: https://www.kbbi.web.id/relevan
Chairunisa, R. A., Sukirman, D., \& Setiawati, L. (2019). Studi implementasi program taqwa character building dalam membangun akhlak siswa di sekolah dasar. Jurnal Penelitian Pendidikan: LPPM Universitas Pendidikan Indonesia, 19(1), 96$105 . \quad$ Retrieved from https:/ / ejournal.upi.edu/index.php/ JER/article/view/17136/9535

Dewi, S. K., \& Garside, A. K. (2014). Perancangan website sebagai media promosi dan penjualan pada home indutry abon. Jurnal Teknik Industri, 15(2), 170-181. https://doi.org/10.22219/JTIUMM.Vol15.No2.170-181

Dipraya, N. W., \& Suwito, D. (2015). Penerapan model pembelajaran thinkpair-share (TPS) pada mata diklat membaca gambar teknik untuk meningkatkan hasil belajar siswa SMK Negeri 7 Surabaya. Jurnal Pendidikan Teknik Mesin UNESA, 4(1), 17-25. Retrieved from https://media.neliti.com/media/pub lications/249347-none-052b37fd.pdf

Ellyusman, W., \& Hutami, R. F. (2017). Analisis kualitas sistem informasi akademik menggunakan metode importance performance analysis (IPA). Kajian Informasi \& Perpustakaan, 5(1), $\quad$ 49-62. https://doi.org/10.24198/jkip.v5i1.11 908

Hanany, N. H., \& Sudirman, E. (2019). Kepuasan pemustaka Perpustakaan UIN Sunan Gunung Djati Bandung dan pengaruh word of mouth pemustaka. Kajian Informasi $\mathcal{E}$ Perpustakaan, $\quad 7(1), \quad$ 95-112. https://doi.org/10.24198/jkip.v7i1.19 130

Johnson, M. A., \& Martin, K. N. (2014). When navigation trumps visual 
dynamism: Hospital website usability and credibility. Journal of Promotion Management, 20(5), 666-687. https:/ / doi.org/10.1080/10496491.20 14.946205

Komariah, N., Rodiah, S., \& Rakhmat, M. Z. (2018). Kegiatan public relations sebagai upaya penguatan eksistensi perpustakaan. Baca Jurnal Dokumentasi Dan Informasi, 39(2), 197-205. https://doi.org/10.14203/j.baca.v39i2 .431

Kusumawati, M. (2013). Faktor-faktor yang mempengaruhi keputusan pasien dalam memilih pelayanan rawat inap kebidanan di Rumah Sakit Islam Jakarta Sukapura dan Rumah Sakit Umum Daerah Koja Jakarta Utara (Tesis) (Universitas Gadjah Mada, Yogyakarta). Retrieved from

http://etd.repository.ugm.ac.id/inde x.php?mod=penelitian_detail\&sub=P enelitianDetail\&act=view \&typ $=\mathrm{html}$ \&buku_id $=56882$

McKinney Jr, E. H., \& Yoos II, C. J. (2019). Information as a difference: Toward a subjective theory of information. European Journal of Information Systems (, 28(4), 1-15. https:/ / doi.org/10.1080/0960085X.20 19.1581441

Nababan, A. J. (2017). Hubungan akun twitter@bem_unpad dengan pemenuhan kebutuhan informasi akademik bagi followers (Skripsi) (Universitas Padjadjaran, Sumedang). Retrieved from

http://pustaka.unpad.ac.id/archives /151082

Oktaviana, A. (2017). Pengaruh kualitas informasi website www.pbhmi.or.id terhadap pemenuhan kebutuhan informasi kader HMI cabang Jatinangor Sumedang (Skripsi). Universitas Padjadjaran,
Jatinangor.

Palindo, A. D. (2019). Pelaksanaan sistem rujukan di Rumah Sakit Alimuddin Umar Kabupaten Lampung Barat berdasarkan Peraturan Menteri Kesehatan no 4 Tahun 2018 tentang kewajiban rumah sakit dan kewajiban pasien (Skripsi) (Universitas Lampung, Lampung). Retrieved from http:/ / digilib.unila.ac.id/57375/3/S KRIPSI TANPA BAB PEMBAHASAN.pdf

Putra, A. S., \& Febriani, O. M. (2013). Sistem informasi monitoring inventori barang pada Balai Riset Standardisasi Industri

Bandar Lampung. Jurnal Informatika, 13(1), 90-98. Retrieved from https://jurnal.darmajaya.ac.id/index. php/JurnalInformatika/article/view /130/pdf

Rumah Sakit Paru Dr. H. A. Rotinsulu. (2019). Rumah Sakit Paru Dr. H. A. Rotinsulu. Retrieved from Rumah Sakit Paru Dr. H. A. Rotinsulu website: http:/ / rsparurotinsulu.org/ Susilowati, S., \& Riasti, B. K. (2011). Pembuatan sistem informasi klinik rawat inap prima Husada Widoro Pacitan berbasis website. Sentra Penelitian Engineering Dan Edukasi, 3(1), 29-34. Retrieved from https://ijns.org/journal/index.php/s peed/article/view/901/889

Syukron, A., \& Hasan, N. (2015). Perancangan sistem informasi rawat jalan berbasis web pada Puskesmas Winong. Jurnal Bianglala Informatika, 3(1), 28-34. https://doi.org/10.31294/bi.v3i1.574. g465

Yusup, P. M. (2017). Ilmu informasi, komunikasi, dan kepustakaan. Jakarta: Kencana Media Group. 


\section{DAFTAR TABEL}

Tabel 1

Hubungan keakuratan informasi pada website RS Dr. H. A. Rotinsulu dengan pemenuhan kebutuhan kognitif

\begin{tabular}{llllllll}
\hline Hubungan & $\begin{array}{l}\text { Koefisien } \\
\text { korelasi }\end{array}$ & $\begin{array}{l}\text { Koefisien } \\
\text { determinasi }\end{array}$ & $\mathbf{t}_{\text {hitung }}$ & $\mathbf{t}_{\text {tabel }}$ & $\mathbf{\alpha}$ & $\begin{array}{l}\text { Kekuatan } \\
\text { korelasi }\end{array}$ & Keputusan \\
\hline $\mathbf{X}_{\mathbf{1} \leftrightarrow \mathbf{Y}_{1}}$ & 0,680 & 0,462 & 6,427 & 1,677 & 0,10 & Kuat & $\mathrm{H}_{0}$ ditolak \\
& & & & & & & $\mathrm{H}_{1}$ diterima
\end{tabular}

Sumber: Hasil pengolahan data, 2018

Tabel 2

Hubungan keakuratan informasi pada website RS Dr. H. A. Rotinsulu dengan pemenuhan kebutuhan integritas personal

\begin{tabular}{lllcccll}
\hline Hubungan & $\begin{array}{l}\text { Koefisien } \\
\text { korelasi }\end{array}$ & $\begin{array}{l}\text { Koefisien } \\
\text { determinasi }\end{array}$ & $\mathbf{t}_{\text {hitung }}$ & $\mathbf{t}_{\text {tabel }}$ & $\mathbf{a}$ & $\begin{array}{l}\text { Kekuatan } \\
\text { korelasi }\end{array}$ & Keputusan \\
\hline $\mathbf{X}_{\mathbf{1}} \leftrightarrow \mathbf{Y}_{2}$ & 0,723 & 0,522 & 7,235 & 1,677 & 0,10 & $\begin{array}{l}\text { Sangat } \\
\text { kuat }\end{array}$ & $\begin{array}{l}\mathrm{H}_{0} \text { ditolak } \\
\mathrm{H}_{1} \text { diterima }\end{array}$ \\
\hline
\end{tabular}

Sumber: Hasil pengolahan data, 2018

Tabel 3

Hubungan ketepatan waktu informasi pada website RS Dr. H. A. Rotinsulu dengan pemenuhan kebutuhan kognitif

\begin{tabular}{llllllll}
\hline Hubungan & $\begin{array}{l}\text { Koefisien } \\
\text { korelasi }\end{array}$ & $\begin{array}{l}\text { Koefisien } \\
\text { determinasi }\end{array}$ & $\mathbf{t}_{\text {hitung }}$ & $\mathbf{t}_{\text {tabel }}$ & $\mathbf{a}$ & $\begin{array}{l}\text { Kekuatan } \\
\text { korelasi }\end{array}$ & Keputusan \\
\hline $\mathrm{X}_{2} \leftrightarrow \mathbf{Y}_{1}$ & 0,567 & 0,321 & 4,766 & 1,677 & 0,10 & Kuat & $\mathrm{H}_{0}$ ditolak \\
& & & & & & & $\mathrm{H}_{1}$ diterima \\
\hline
\end{tabular}

Sumber: Hasil pengolahan data, 2018

Tabel 4

Hubungan ketepatan waktu informasi pada website RS Dr. H. A. Rotinsulu dengan pemenuhan kebutuhan integritas personal

\begin{tabular}{lllllllll}
\hline Hubungan & $\begin{array}{l}\text { Koefisien } \\
\text { korelasi }\end{array}$ & $\begin{array}{l}\text { Koefisien } \\
\text { determinasi }\end{array}$ & $\mathbf{t}_{\text {hitung }}$ & $\mathbf{t}_{\text {tabel }}$ & $\mathbf{a}$ & $\begin{array}{l}\text { Kekuatan } \\
\text { korelasi }\end{array}$ & Keputusan \\
\hline $\mathbf{X}_{2} \leftrightarrow \mathbf{Y}_{2}$ & 0,608 & 0,369 & 5,304 & 1,677 & 0,10 & Kuat & $\begin{array}{l}\mathrm{H}_{0} \text { ditolak } \\
\mathrm{H}_{1} \text { diterima }\end{array}$ \\
\hline
\end{tabular}

Sumber: Hasil pengolahan data, 2018 
Tabel 5

Hubungan relevansi informasi pada website RS Dr. H. A. Rotinsulu dengan pemenuhan kebutuhan kognitif

\begin{tabular}{llllllll}
\hline Hubungan & $\begin{array}{l}\text { Koefisien } \\
\text { korelasi }\end{array}$ & $\begin{array}{l}\text { Koefisien } \\
\text { determinasi }\end{array}$ & $\mathbf{t}_{\text {hitung }}$ & $\mathbf{t}_{\text {tabel }}$ & $\mathbf{a}$ & $\begin{array}{l}\text { Kekuatan } \\
\text { korelasi }\end{array}$ & Keputusan \\
\hline $\mathbf{X}_{3} \leftrightarrow \mathbf{Y}_{1}$ & 0,661 & 0,436 & 6,105 & 1,677 & 0,10 & Kuat & $\mathrm{H}_{0}$ ditolak \\
& & & & & & & $\mathrm{H}_{1}$ diterima
\end{tabular}

Sumber: Hasil pengolahan data, 2018

Tabel 6

Hubungan ketepatan waktu informasi pada website RS Dr. H. A. Rotinsulu dengan pemenuhan kebutuhan integritas personal

\begin{tabular}{llllllll}
\hline Hubungan & $\begin{array}{l}\text { Koefisien } \\
\text { korelasi }\end{array}$ & $\begin{array}{l}\text { Koefisien } \\
\text { determinasi }\end{array}$ & $\mathbf{t}_{\text {hitung }}$ & $\mathbf{t}_{\text {tabel }}$ & $\mathbf{a}$ & $\begin{array}{l}\text { Kekuatan } \\
\text { korelasi }\end{array}$ & Keputusan \\
\hline $\mathbf{X}_{2} \leftrightarrow \mathbf{Y}_{2}$ & 0,608 & 0,369 & 5,304 & 1,677 & 0,10 & Kuat & $\begin{array}{l}\mathrm{H}_{0} \text { ditolak } \\
\end{array}$ \\
& & & & & & $\mathrm{H}_{1}$ diterima \\
\hline
\end{tabular}

Sumber: Hasil pengolahan data, 2018 